\title{
Inkretintengelyen ható antidiabetikumok és a pancreas betegségei (pancreatitis, pancreascarcinoma)
}

\author{
Jermendy György dr. \\ Bajcsy-Zsilinszky Kórház, Budapest
}

\begin{abstract}
Az inkretintengelyen ható készítmények egyre népszerúbbek a 2-es típusú diabetes kezelése terén. A forgalomba kerülés után röviddel esetközlések, majd kisszámú betegcsoportban tett megfigyelések jelentek meg, amelyek az adott készítmények potenciális mellékhatására hívták fel a figyelmet. A figyelem középpontjába a pancreas betegségei (pancreatitis acuta, pancreascarcinoma) kerültek. A klinikai megfigyelések egyre szaporodtak, a ritka mellékhatást lényegében mindegyik inkretinkészítménnyel kapcsolatban megfigyelték. A potenciális mellékhatásként jelentkező pancreatitis és pancreascarcinoma kérdéskörével kapcsolatban intenzív szakmai vita bontakozott ki, amelynek során a szakértók mellett a gyógyszeripar képviselói, a nemzetközi tudományos társaságok és a gyógyszerügyi hatóságok is kifejtették álláspontjukat. A mellékhatásokat nagy klinikai tanulmányokban és metaanalízisekben is elemezték. A klinikai gyakorlatban az adott, választandó inkretinkészítmény alkalmazási előírásában foglaltakat kell követni. Óvatosság ajánlott azoknál a betegeknél, akiknek anamnézisében pancreatitis szerepel. Ha az inkretintengelyen ható készítménnyel folytatott terápia során a betegnek hasi panasza támad, annak természetét tisztázni kell. Ha a pancreatitis kórisméje megerősíthető, az adott készítmény adását véglegesen fel kell függeszteni. Az inkretintengelyen ható készítményekkel kapcsolatban továbbra is indokolt a posztmarketing adatgyúijtés és mellékhatás-elemzés. Orv. Hetil., 2016, $157(14), 523-528$.
\end{abstract}

Kulcsszavak: diabetes mellitus, inkretinek, GLP-1-mimetikumok, DPP-4-gátlók, pancreatitis, pancreascarcinoma

\section{Incretin-based antidiabetic treatment and diseases of the pancreas (pancreatitis, pancreas carcinoma)}

In the last couple of years incretin-based antidiabetic drugs became increasingly popular and widely used for treating patients with type 2 diabetes. Immediately after launching, case reports and small case series were published on the potential side effects of the new drugs, with special attention to pancreatic disorders such as acute pancreatitis or pancreatic cancer. As clinical observations accumulated, these side-effects were noted with nearly all drugs of this class. Although these side-effects proved to be rare, an intensive debate evolved in the literature. Opinion of diabetes specialists and representatives of pharmaceutical industry as well as position statements of different international scientific boards and health authorities were published. In addition, results of randomized clinical trials with incretinbased therapy and meta-analyses became available. Importantly, in everyday clinical practice, the label of the given drug should be followed. With regards to incretins, physicians should be cautious if pancreatitis in the patients' past medical history is documented. Early differential diagnosis of any abdominal pain during treatment of incretin-based therapy should be made and the drug should be discontinued if pancreatitis is verified. Continuous post-marketing surveillance and side-effect analysis are still justified with incretin-based antidiabetic treatment in patients with type 2 diabetes.

Keywords: diabetes mellitus, incretins, GLP-1-mimetics, DPP-4-inhibitors, pancreatitis, pancreas carcinoma

Jermendy, Gy. [Incretin-based antidiabetic treatment and diseases of the pancreas (pancreatitis, pancreas carcinoma)]. Orv. Hetil., 2016, 157(14), 523-528.

(Beérkezett: 2016. január 19.; elfogadva: 2016. február 10.) 


\section{Rövidítések}

$\mathrm{ADA}=$ (American Diabetes Association) Amerikai Diabetes Társaság; DPP-4 = dipeptidilpeptidáz-4; EASD = (European Association for the Study of Diabetes) Európai Diabetes Társaság; ELIXA (vizsgálat) = Evaluation of lixisenatide in acute coronary syndrome; EMA = (European Medicines Agency) Európai Gyógyszerügyi Hatóság; EXAMINE (vizsgálat) = Examination of cardiovascular outcomes with alogliptin versus standard of care; FDA = (U.S. Food and Drug Administration $)$ Amerikai Gyógyszerügyi Hatóság; GLP-1 = glükagonszerú peptid-1; IDF $=($ International Diabetes Federation $)$ Nemzetközi Diabetes Szövetség; SAVOR (vizsgálat) = Saxagliptin Assessment of Vascular Outcomes Recorded in patients with diabetes mellitus; TECOS (vizsgálat) $=$ Trial Evaluating Cardiovascular Outcomes with Sitagliptin

Az inkretintengelyen ható készítmények egyre népszerúbbek a 2-es típusú diabetes kezelése terén. A forgalomba kerülés után röviddel esetközlések, majd kisszámú betegcsoportban tett megfigyelések jelentek meg, amelyek az adott készítmények potenciális mellékhatására hívták fel a figyelmet. Az első közlések az exenatiddal, majd a sitagliptinnel kapcsolatban jelentek meg, ennek az volt az egyszerú oka, hogy ezek a készítmények jelentek meg elsőként az adott hatástani alcsoporton (GLP-1mimetikumok, DPP-4-gátlók) belül. A figyelem középpontjába a pancreas betegségei (pancreatitis acuta, pancreascarcinoma) kerültek, bár a liraglutiddal kapcsolatban később a pajzsmirigy-carcinomával való esetleges összefüggés lehetősége is felmerült. A klinikai megfigyelések egyre szaporodtak, köztük kohorsztanulmányok, eset-kontroll vizsgálatok, farmakovigilancia- és regiszteradatok, más antidiabetikumokkal történő összehasonlítások találhatók [1-14]. Az évek során a nemkívánatos mellékhatásként jelentkező pancreatitisesemények száma nőtt, s azt lényegében mindegyik inkretinkészítménnyel kapcsolatban megfigyelték.

$\mathrm{Az}$ inkretintengelyen ható készítmények potenciális mellékhatásaként jelentkező pancreatitis és pancreascarcinoma kérdéskörével kapcsolatban intenzív szakmai vita bontakozott ki, amelynek során a szakértók mellett a gyógyszeripar képviselói is kifejtették álláspontjukat. A szakértők között a potenciális veszély hangoztatása elsősorban Butler és mtsai nevéhez kötődik [15], akik 2013-ban egy azóta elhíresült humán autopsziás anyag feldolgozása során tett megfigyeléseiket közölték [16]. Ugyanakkor a túlzott aggodalom indokolatlanságát is számosan hangoztatták, akik között talán Nauck álláspontja tekinthetô a leginkább mérvadónak [17]. Nem véletlen, hogy a Diabetes Care hasábjain a szerkesztőség - átérezve azt, hogy a kibontakozó szakmai vita kapcsán a szakmai folyóiratoknak is felelősségük van - helyt adott az ellentétes szakmai vélemények egyidejü kifejtésének, szerkesztőségi kommentár kíséretében [18]. Érdekes körülmény, hogy a nagy vihart kavart Butler-közlemény metodikai megbízhatóságát később erős kritikával illették [19]. A szakmai vitában megszólaltak a hatóságok (FDA, EMA), illetve a tudományos társaságok (ADA, EASD, IDF) is [20, 2l]. A vita csúcspontja óta eltelt mintegy két évben az inkretintengelyen ható készítményekkel folytatott randomizált nagy klinikai tanulmányok (SAVOR, EXAMINE, TECOS, ELIXA) ezen a téren is új adatokkal bővítették ismereteinket. Ezek alapján megfogalmazhatók azok a szakmai javaslatok, amelyek a gyakorlat számára napjainkban útmutatásul szolgálhatnak.

\section{Ok-okozati összefüggés és klinikai relevancia: érvek-ellenérvek}

Butler és mtsai rámutattak arra, hogy a GLP-1-receptorok a pancreasban megtalálhatók, expressziójuk meglehetősen markáns a pancreas ductusaiban, az acinusokban és a szigetsejtekben egyaránt [15]. A GLP-1-terápia hatására a sejtek proliferációja következhet be, aminek eredményeképpen a pancreas tömege nő. Ennek a ténynek kevés jelentőséget tulajdonítottak mindaddig, amíg 2009-ben egy állatmodellben azt nem találták, hogy sitagliptin hatására pancreatitis haemorrhagica alakult ki, s a ductusokban premalignusnak minősíthető metaplasia jelei váltak felismerhetókké [22]. Ezt követően további állatkísérletes publikációk is napvilágot láttak. Az idő múlásával a klinikai körülmények között megfigyelt pancreatitisesetek száma az irodalomban egyre gyarapodott, Butler és mtsai 2013-ban publikált közleményében [15] az alábbi esetszámok találhatók: exenatid 2327, sitagliptin 718, liraglutid 888, saxagliptin 125, linagliptin 43. Az igazi tudományos szenzáció az volt, amikor Butler és mtsai 2013-ban a Diabetes hasábjain humán autopsziás vizsgálataik hisztopatológiai eredményeit közölték [16]. Vizsgálataik során agysérülésben elhalt betegek pancreasát dolgozták fel. A tanulmányban 2-es típusú diabetesben szenvedó 20 cukorbeteg szerepelt, akiket két csoportba osztottak. Nyolcfós csoportot alkottak azok a betegek, akik haláluk előtt legalább 1 évig inkretintengelyen ható készítményt szedtek (7 fó sitagliptint, 1 fó exenatidot), 12 fó cukorbeteg volt, de inkretintengelyen ható terápiában nem részesültek. Végül volt egy 14 fös kontrollcsoport is (nem cukorbetegek). Az inkretinterápiát folytató betegek esetében a pancreas tömege nőtt, a növekedés érintette mind az endokrin, mind az exokrin állományt. Az exokrin állományban a növekedést proliferáció és dysplasia jellemezte, az endokrin állományban (az $\alpha$-sejtekben) a hyperplasiát a szerzők az esetek egy részében potenciális neuroendokrin tumorként írták le.

Nauck a vitatott kérdést inkább klinikai szempontból közelítette meg [17]. Leírta, hogy inkretinterápiában részesülő cukorbetegek körében szórványosan kétségtelenül leírtak pancreatitiseseteket, a kérdés azonban az, hogy ezen a téren van-e olyan gyakoriságnövekedés, amely az adott inkretinkészítménnyel összefüggésbe hozható lenne, illetve igazolni kell, hogy a megfigyelt pancreatitis az adott antidiabetikum használatával kétség 
kívül oki összefüggésben áll-e vagy sem. Rámutatott arra, hogy 2-es típusú cukorbetegségben a pancreatitis önmagában gyakrabban fordulhat elő, az adatbázisok, a mellékhatás-bejelentések összesített értékelése számos bizonytalansággal terhelt, a szérumamiláz és -lipáz mérsékelt emelkedése nem azonos a pancreatitis acuta klinikai diagnózisával. A pancreascarcinoma ismert módon általában klinikailag tünetszegényen fejlődik, a panaszok/tünetek alapján történt felismerésekor elég jellemzően már előrehaladott folyamattal állunk szemben. A krónikus hyperplasia nem nevezhető daganatnak, az inkább csak kockázati tényezőként értékelhető ebben a vonatkozásban. A pancreatitis chronica klinikai képe jól ismert (fogyás, hasmenés, hasi fájdalom), a betegekben megfigyelt, inkretinterápia során kialakuló mellékhatás (hasi panasz, gastrointestinalis tünetek) klinikai képére ezek a tünetek nem voltak jellemzők. Az irodalomban nem írtak le egyetlen olyan beteget sem, akinél igazoltan tumormentes állapotban elindított inkretinterápia során pancreascarcinoma alakult volna ki. Ismert az is, hogy a diabetes önmagában egybeesik a pancreasdaganat előfordulásának gyakoribb voltával. Végül a pancreatitis kialakulásának okát a zajló inkretinterápiával igen nehéz határozott oki összefüggésbe hozni, a számos potenciális zavaró körülmény miatt (ismert, hogy pancreatitis gyakrabban alakul ki epekövességben, lipideltérés, elhízás, esetleg alkoholfogyasztás esetén - ezek a körülmények nem ritkák 2-es típusú cukorbetegségben). Végezetül kiemelte, hogy a klinikai tevékenységet, így a cukorbetegek antihyperglykaemiás kezelésének megválasztását is, mindig a várható előnyök és a potenciális kockázatok gondos mérlegelése jelenti. Az inkretintengelyen ható készítmények előnyét számos klinikai vizsgálat nagyszámú beteg esetében igazolta, a potenciális kockázatot ehhez viszonyítva elenyésző számban figyelték meg. A leírt mellékhatás (pancreatitis, pancreascarcinoma) és a zajló inkretinterápia közötti oki összefüggést inkább a bizonytalanság, semmint a határozott egyértelmúség jellemezte. Ebből adódóan az inkretinterápia előnyei messze magasan felülmúlják az alkalmazás kockázatát, ezért a készítmények nyugodtan használhatók a napi klinikai gyakorlatban. A további adatgyưjtés (posztmarketing surveillance) és ezek alapján a helyzet időszakos újraértékelése természetesen továbbra is indokolt.

\section{A Butler-tanulmány kritikája}

Miután Butler és mtsai az első humán autopsziás, hisztomorfológiai megfigyeléseikről tudósítottak, azok klinikai relevanciája messze magasan felülmúlja az experimentális diabetesben nyert adatokét. Éppen ezért alapvető fontosságú az alkalmazott metodika megbízhatósága. Bonner-Weir és mtsai, a Joslin Diabetes Center (Harvard University, Boston) kutatói, a szigetsejt-morfológia kiváló szakemberei 2014-ben áttekintették a Butler-tanulmányban szereplő 34 beteg klinikai adatait és hisztológiai mintáit. Arra a következtetésre jutottak, hogy a tanulmány olyan súlyos metodikai bizonytalanságokkal terhelt, hogy azok kizárják az érdemi következtetések levonását [19].

\section{A szakmai társaságok (ADA, EASD, IDF) állásfoglalása}

A szakmai vita során az Amerikai Diabetes Társaság (ADA), az Európai Diabetes Társaság (EASD), illetve a Nemzetközi Diabetes Szövetség (IDF) közös állásfoglalást tett közzé 2013-ban [20]. Leírták, hogy a közelmúltban váltak ismertté azoknak az epidemiológiai jellegü, állatkísérletes és humán autopsziás vizsgálatoknak az eredményei, amelyek kétséget ébresztettek az inkretinterápia biztonságosságával kapcsolatban. Elsősorban a sitagliptin és az exenatid került a figyelem középpontjába, miután ezeket a gyógyszereket használják legrégebben - következésképpen a gyógyszer-expozíció ezeknél a szereknél a leghosszabb. Annak lehetősége merült fel, hogy ezeknek a készítményeknek a szedése olyan pancreaselváltozásokkal állhat összefüggésben, amelyek a pancreatitistől a premalignus elváltozásokig terjednek. Egy hatósági munkabizottság 2013 júniusában áttekintette a diabetes és a pancreascarcinoma közötti epidemiológiai jellegü összefüggéseket, s azt állapították meg, hogy a malignus kórkép kockázata közel 82\%-kal nő, függetlenül a terápiától. Az FDA ismertette a preklinikai patológiai jellegú adatokat, amelyeket az összes készítménnyel kapcsolatban végeztek, s nem találtak aggályt a pancreasbetegség vonatkozásában. A humán autopsziás vizsgálatoknak komoly módszertani korlátai voltak, s felmerült, hogy a szerzők által talált eltéréseknek más magyarázata is lehet.

A diabetes által érintett betegek nagy létszámú és változatos köre a hatékony és biztonságos gyógyszeres terápiák széles körét igényli. Az ADA, az EASD és az IDF szilárdan hisz abban, hogy a gyógyszereket szedő betegeket, illetve a készítményeket ajánló egészségügyi dolgozókat tájékoztatni kell a gyógyszerek előnyéről és lehetséges kockázatairól annak érdekében, hogy a lehetséges legjobb döntést lehessen meghozni a terápia terén. Jelenleg nem áll rendelkezésre elegendő információ ahhoz, hogy annak alapján az antidiabetikus kezelés megváltoztatását kellene kezdeményezni. Az egészségügyi dolgozóknak azonban figyelembe kell venni a betegek terápiás válaszát és a készítmények mellékhatásprofilját akkor, amikor az aktuális terápiát fenntartani vagy megváltoztatni szándékoznak.

\section{Gyógyszerügyi hatóságok állásfoglalása}

Az inkretintengelyen ható készítmény biztonságosságával, a pancreatitis/pancreasdaganat kérdésével kapcsolatban 2014-ben közös közleményt jelentetett meg az amerikai (U.S. Food and Drug Administration - FDA) és az európai gyógyszerügyi hatóság (European Medici- 
nes Agency - EMA) [21]. Mindkét hatóság folyamatosan értékelte az inkretintengelyen ható regisztrált készítmények (GLP-1-mimetikumok: exenatid, liraglutid, lixisenatid; DPP-4-gátlók: sitagliptin, vildagliptin, saxagliptin, linagliptin, alogliptin) forgalomba hozatala óta ismertté vált biztonságossági jelzéseket. Különös figyelmet fordítottak Butler és mtsai 2013-ban napvilágot látott, humán autopsziás tanulmányára.

A két hatóság közös közleménye kitér arra, hogy áttekintették a gyógyszerfejlesztés során kötelező toxikológiai adatokat, az állatkísérletes vizsgálatok eredményeit, a diabeteses rágcsálókban végzett tanulmányok hisztopatológiai adatait, a klinikai tanulmányok eredményeit, azok metaanalízését, a két befejezett cardiovascularis biztonságossági vizsgálat (SAVOR, EXAMINE) adatait, illetve az obszervációs adatgyújtések eredményeit, s ezek alapján foglaltak állást.

A két hatóság álláspontja szerint a rendelkezésre álló adatok nem támasztják alá azt a - szaklapokban és a médiában nagy nyilvánosságot kapó - vélekedést, amely szerint oki összefüggés lenne az inkretintengelyen ható gyógyszerek használata és a pancreatitis/pancreasdaganat kialakulása között. Jelenleg nincs szükség az alkalmazási előírások módosítására. Mindazonáltal a további adatgyưjtés indokolt, a két hatóság közös álláspontja nem jelent végső konklúziót. A betegek kórelőzményében szereplő pancreatitis továbbra is kockázati tényezőt jelent, amit az adott gyógyszer alkalmazási elő́rásában rögzítetteknek megfelelően kell értékelni.

\section{Nagy klinikai tanulmányok (SAVOR, EXAMINE, TECOS, ELIXA) eredményei}

Hatósági elő́rás nyomán az inkretintengelyen ható új antidiabetikumokkal a cardiovascularis biztonságosság megítélése érdekében nagy, randomizált, placebokontrollos klinikai vizsgálatokat indítottak az elmúlt években. Mind ez ideig négy vizsgálat fejeződött be. A vizsgálatok, az elsődleges célkitűzésnek megfelelően, a cardiovascularis biztonságosságot igazolták, de - a bevont betegek nagy száma, a vizsgálat prospektív és placebokontrollos jellege folytán - a szakmai közvélemény érdeklődéssel várta a mellékhatások alakulását is. A pancreatitis, pancreascarcinoma, daganatos betegségek elöfordulásáról mindegyik tanulmány tudósított.
A SAVOR vizsgálatba (saxagliptin versus placebo) 16492 beteget vontak be (saxagliptinág: $n=8280$, placeboág: $\mathrm{n}=8212$ ), a követés medián tartama 2,1 év volt. A pancreatitis előfordulása azonos gyakoriságú volt a két kezelési ágon (akut pancreatitis 0,3\%, krónikus pancreatitis $<0,1 \%$ a saxagliptinágon, $0,2 \%$ és $0,1 \%$ a placeboágon). A saxagliptinágon 5 , a placeboágon 12 pancreastumor-esetet regisztráltak [23].

Az EXAMINE vizsgálatba (alogliptin versus placebo) 5380 beteget vontak be (alogliptinág: $\mathrm{n}=2701$, placeboág: $\mathrm{n}=2679$ ), a követés medián tartama 1,5 év volt. Az alogliptinág és a placeboág nem különbözött egymástól a súlyos nemkívánatos események gyakoriságát tekintve. Nem volt különbség a pancreatitis és a daganatos betegségek gyakoriságát tekintve a két ág között. Pancreascarcinoma előfordulását nem észlelték [24].

A TECOS vizsgálatba (sitagliptin versus placebo) 14671 beteget vontak be (sitagliptinág: $\mathrm{n}=7332$, placeboág: $n=7339$ ), a követés medián tartama 3,0 év volt. Pancreatitis acuta valamelyest nagyobb számban a sitagliptinágon, daganatos betegségek, pancreasrák valamelyest nagyobb számban a placeboágon fordult elö, de értékelhető statisztikai különbség nem mutatkozott a két csoport összehasonlítása során (1. táblázat) [25].

$\mathrm{Az}$ ELIXA vizsgálatba (lixisenatid versus placebo) 6068 beteget vontak be (lixisenatidág: $\mathrm{n}=3034$, placeboág: $\mathrm{n}=3034$ ), a követés medián tartama 2 év volt. A két ág között nem volt érdemi különbség a pancreatitis ( 5 versus 8 eset), illetve a pancreasrák (3 versus 9 eset) között, számszerúen a pancreasbetegségek valamelyest nagyobb számban fordultak elő a placeboágon [26].

A tanulmányok összesített értékelése alapján megállapítható, hogy a többezres betegpopuláció néhány éves követése során egyetlen vizsgálat sem igazolta a pancreatitis vagy a pancreascarcinoma előfordulási gyakoriságának értékelhető növekedését. A fent áttekintett vizsgálatok közül különösen értékes ebben a vonatkozásban a TECOS, mert azt a korábban hírbe hozott sitagliptinnel folytatták.

\section{Metaanalízisek eredményei}

A GLP-1-mimetikumok (exenatid, liraglutid, lixisenatid, albiglutid, dulaglutid, semaglutid, taspoglutid) bevonásával zajló klinikai tanulmányok metaanalízise során öszszesen 14972 beteg adatait elemezték Monami és mtsai

1. táblázat | TECOS vizsgálat: a pancreatitis, a daganatos betegségek és a pancreascarcinoma alakulása (per protokoll analízis) [25]

\begin{tabular}{|c|c|c|c|c|}
\hline \multirow[t]{2}{*}{ Kimeneteli esemény } & $\begin{array}{l}\text { Sitagliptin } \\
(\mathrm{n}=7257)\end{array}$ & $\begin{array}{l}\text { Placebo } \\
(\mathrm{n}=7266)\end{array}$ & \multirow[t]{2}{*}{$\begin{array}{l}\text { Esélyhányados } \\
(95 \% \mathrm{CI})\end{array}$} & \multirow[t]{2}{*}{ P értéke } \\
\hline & $\begin{array}{l}\text { Eseményt elszenvedett betegek száma (\%); } \\
\text { esemény/100 betegév }\end{array}$ & $\begin{array}{l}\text { Eseményt elszenvedett betegek száma (\%); } \\
\text { esemény/100 betegév }\end{array}$ & & \\
\hline Akut pancreatitis & $20(0,3 \%) ; 0,10$ & $11(0,2 \%) ; 0,06$ & $1,80(0,86-3,76)$ & 0,12 \\
\hline Daganatos betegségek & $248(0,3 \%) ; 1,30$ & $260(3,6 \%) ; 1,40$ & $0,93(0,78-1,10)$ & 0,38 \\
\hline Pancreasrák & $9(0,1 \%) ; 0,05$ & $10(0,1 \%) ; 0,05$ & $0,91(0,37-2,25)$ & 0,85 \\
\hline
\end{tabular}


[27]. A pancreatitis nem fordult elő gyakrabban a GLP1-mimetikumot kapók (versus komparátor szert használók) körében.

Egy 2014-ben közölt másik metaanalízisben 60 tanulmány 353639 betegének történetét tekintették át, a betegek GLP-1-mimetikumot vagy DPP-4-gátlót kaptak. A metaanalízisben 55 randomizált, kontrollált vizsgálat (betegszám 33 350) és 5 obszervációs jellegü (3 retrospektív kohorsz és 2 eset-kontroll) tanulmány (betegszám 320289 ) szerepelt. A szerzők végkövetkeztetése szerint az inkretintengelyen ható gyógyszerek használata során a pancreatitis incidenciája igen alacsony, a gyógyszer adása nem növeli a pancreatitis kockázatát. Mindazonáltal ez a vélemény nem tekinthető véglegesnek, a további adatgyújtés még mindig indokolt [28].

\section{Gyakorlati következtetések}

Az inkretintengelyen ható készítmények és a pancreasbetegségek közötti oki összefüggés szakmai vitája napjainkra sokat csitult, bár teljes tisztánlátásról tíz évvel az elsó készítmény piacra kerülése után sem beszélhetünk még [29]. Az eseményekből gyakorlati következtetések vonhatók le.

A klinikusnak az adott, választandó inkretinkészítmény alkalmazási elő́rásában foglaltakat kell követni. Ezek nyilvánvalóan nem teljesen azonos szövegúek, de mindegyik megegyezik abban, hogy óvatosság ajánlott azoknál a cukorbetegeknél, akiknek kórelőzményi adatai között pancreatitis szerepel. Ha a beteg ezt az anamnesztikus adatot említi, célszerúbbnek látszik más hatástani csoportból választani az antihyperglykaemiás kezelés indításakor. $\mathrm{Ha}$ az inkretinterápia megkezdése után a betegnél hasi diszkomfort, hányinger, esetleg hányás alakul ki, gondolni kell arra, hogy a tünetek hátterében nem áll-e fenn pancreatitis, mint ritka mellékhatás. Ilyen esetekben törekedni kell a pontos kórisme megállapítására, s a megfelelő kezelésre. Adott esetben a választott inkretinkészítmény adásának végleges felfüggesztése is indokolttá válhat. Ha a pancreatitis kórisméje megállapítást nyert, a készítményt nem szabad újrakezdeni.

Végezetül nem szabad megfeledkeznünk arról, hogy a posztmarketing adatgyűjtés és mellékhatás-bejelentés minden gyakorló orvos számára előírt kötelezettség, mert az ennek során gyarapodó ismeretek tovább szolgálhatják majd az inkretintengelyen ható készítményekkel kapcsolatos ismeretek bővülését.

Általánosságban véve nem vitás, hogy a gyógyszerek piacra kerülése után igen nagy jelentősége van a szisztematikus adatgyưjtésnek, mert több ízben előfordult, hogy így vált felismerhetővé olyan mellékhatás, amely a gyógyszer fejlesztése során nem került látótérbe. Ebben a folyamatban minden résztvevőnek (gyógyszeripar, forgalmazók, hatóság, orvosi közösségek, gyakorló orvosok, betegek) fontos szerepe van. A helyzetet bonyolítja, hogy néhány éve új szereplőként az írott és az elektronikus média is megjelent [18]. A gyakorló orvosoknak nem az utóbbi hírforrásokból kell tájékozódniuk.

Anyagi támogatás: A közlemény megírása anyagi támogatásban nem részesült.

A kézirat végleges változatát a szerző elolvasta és jóváhagyta.

Érdekeltségek: A szerzőnek nincsenek érdekeltségei.

\section{Irodalom}

[1] Raschi, E., Piccinni, C., Poluzzi E., et al.: The association of pancreatitis with antidiabetic drug use: gaining insight through the FDA pharmacovigilance database. Acta Diabetol., 2013, 50(4), 569-577.

[2] Faillie, J. L., Babai, S., Crepin, S., et al.: Pancreatitis associated with the use of GLP-1 analogs and DPP-4 inhibitors: a case/ non-case study from the French Pharmacovigilance Database. Acta Diabetol., 2014, 51(3), 491-497.

[3] Dore, D. D., Seeger, J. D., Arnold Chan, K.: Use of a claims-based active drug safety surveillance system to assess the risk of acute pancreatitis with exenatide or sitagliptin compared to metformin or glyburide. Curr. Med. Res. Opin., 2009, 25(4), 1019-1027.

[4] Garg, R., Chen, W., Pendergrass, M.: Acute pancreatitis in type 2 diabetes treated with exenatide or sitagliptin: a retrospective observational pharmacy claims analysis. Diabetes Care, 2010, 33(11), 2349-2354.

[5] Dore, D. D., Bloomgren, G. L., Wenten, M., et al.: A cohort study of acute pancreatitis in relation to exenatide use. Diabetes Obes. Metab., 2013, 13(6), 559-566.

[6] Romley, J. A., Goldman, D. P., Solomon, M., et al.: Exenatide therapy and the risk of pancreatitis and pancreatic cancer in a privately insured population. Diabetes Technol. Ther., 2012, 14(10), 904-911.

[7] Wenten, M., Gaebler, J. A., Hussein, M., et al.: Relative risk of acute pancreatitis in initiators of exenatide twice daily compared with other anti-diabetic medication: a follow-up study. Diabet. Med., 2012, 29(11), 1412-1418.

[8] Eurich, D. T., Simpson, S., Senthilselvan, A., et al.: Comparative safety and effectiveness of sitagliptin in patients with type 2 diabetes: retrospective population based cohort study. BMJ, 2013, $346, \mathrm{f} 2267$.

[9] Funch, D., Gydesen, H., Tornøe, K., et al.: A prospective, claimsbased assessment of the risk of pancreatitis and pancreatic cancer with liraglutide compared to other antidiabetic drugs. Diabetes Obes. Metab., 2014, 16(3), 273-275.

[10] Giorda, C. B., Picariello, R., Nada, E., et al.: Incretin therapies and risk of hospital admission for acute pancreatitis in an unselected population of European patients with type 2 diabetes: a case-control study. Lancet Diabetes Endocrinol., 2014, 2(2), 111-115.

[11] Faillie, J. L., Azoulay, L., Patenaude, V., et al.: Incretin based drugs and risk of acute pancreatitis in patients with type 2 diabetes: cohort study. BMJ, 2014, 348, g2780.

[12] Chou, H. C., Chen, W. W., Hsiao, F. Y.: Acute pancreatitis in patients with type 2 diabetes mellitus treated with dipeptidyl peptidase- 4 inhibitors: a population-based nested case-control study. Drug Saf., 2014, 37(7), 521-528.

[13] Thomsen, R. W., Pedersen, L., Moller, N., et al.: Incretin-based therapy and risk of acute pancreatitis: a nationwide population- 
based case-control study. Diabetes Care, 2015, 38(6), 10891098

[14] Gonzalez-Perez, A., Schlienger, R. G., Rodriguez, L. A.: Acute pancreatitis in association with type 2 diabetes and antidiabetic drugs: a population-based cohort study. Diabetes Care, 2010, 33(12), 2580-2585.

[15] Butler, P. C., Elashoff, M., Elashoff, R., et al.: A critical analysis of the clinical use of incretin-based therapies: Are the GLP-1 therapies safe? Diabetes Care, 2013, 36(7), 2118-2125.

[16] Butler, A. E., Campbell-Thompson, M., Gurlo, T., et al.: Marked expansion of exocrine and endocrine pancreas with incretin therapy in humans with increased exocrine pancreas dysplasia and the potential for glucagon-producing neuroendocrine tumors. Diabetes, 2013, 62(7), 2595-2604.

[17] Nauck, M. A.: A critical analysis of the clinical use of incretinbased therapies: The benefits by far outweigh the potential risks. Diabetes Care, 2013, 36(7), 2126-2132.

[18] Cefalu, W. T., Rosenstock, J., Henry, R. R., et al.: Signals and noise in drug safety analyses: the incretin therapy debate provides the rationale for revamping epidemiologic pharmacovigilance. Diabetes Care, 2013, 36(7), 1804-1806.

[19] Bonner-Weir, S., In't Veld, P. A., Weir, G. C.: Reanalysis of study of pancreatic effects of incretin therapy: methodological deficiencies. Diabetes Obes. Metab., 2014, 16(7), 661-666.

[20] ADA/EASD/IDF Recommendations for clinicians and people with diabetes concerning the use of incretin therapy and pancreatic disease. www.easd.org

[21] Egan, A. G., Blind, E., Dunder, K., et al.: Pancreatic safety of incretin-based drugs - FDA and EMA assessment. N. Eng. J. Med., 2014, 370(9), 794-797.

[22] Matveyenko, A. V., Dry, S., Cox, H. I., et al.: Beneficial endocrine but adverse exocrine effects of sitagliptin in the human islet amy- loid polypeptide transgenic rat model of type 2 diabetes: interac tions with metformin. Diabetes, 2009, 58(7), 1604-1615.

[23] Scirica, B. M., Bhatt, D. L., Braunwald, E., et al.: Saxagliptin and cardiovascular outcomes in patients with type 2 diabetes mellitus. N. Engl. J. Med., 2013, 369(14), 1317-1326.

[24] White, W. B., Cannon, C. P., Heller, S. R., et al.: Alogliptin after acute coronary syndrome in patients with type 2 diabetes. N. Engl. J. Med., 2013, 369(14), 1327-1335.

[25] Green, J. B., Bethel, M. A., Armstrong, P. W., et al.: Effect of sitagliptin on cardiovascular outcomes in type 2 diabetes. N. Engl. J. Med., 2015, 373(3), 232-242

[26] Pfeffer, M. A., Claggett, B., Diaz, R., et al.: Lixisenatide in patients with type 2 diabetes and acute coronary syndrome. $\mathrm{N}$. Engl. J. Med., 2015, 373(23), 2247-2257.

[27] Monami, M., Dicembrini, I., Nardini, C., et al.: Glucagon-like peptide- 1 receptor agonists and pancreatitis: a meta-analysis of randomized clinical trials. Diabetes Res. Clin. Pract., 2014, $103(2), 269-275$

[28] Li, L., Shen, J., Bala, M. M., et al.: Incretin treatment and risk of pancreatitis in patients with type 2 diabetes mellitus: systematic review and meta-analysis of randomised and non-randomised studies. BMJ, 2014, 348, g2366.

[29] Azoulay, L.: Incretin-based drugs and adverse pancreatic events: almost a decade later and uncertainty remains. Diabetes Care, $2015,38(6), 951-953$

\section{FELHÍVÁS \\ folyóirat-referátumok beküldésére}

A Semmelweis Egyetem Továbbképző Központjának döntése értelmében

2016. január 1-jétöl folyamatosan orvos-továbbképzési pontokat kaphatnak a nemzetközi, impaktfaktoros folyóiratokban megjelent közlemények rövid összefoglalásának, referátumának beküldői.

Az Orvosi Hetilap hasábjain megjelenő és közlésre elfogadott referátum után 1 pont, félévente maximum 12 továbbképzési pont gyưjithető, amelyet félévente összesitve továbbitunk a továbbképzési központok felé.

Távoktatással szerzett pontokból évente legfeljebb 20 pont számitható be.

Aki továbbképzési pontot kíván gyüjteni, a referátum beküldésekor adja meg pecsétszámát.

Várjuk lelkes, továbbképzési pontokat gyüjteni kivánó referálóink jelentkezését!

\section{A referátum fejlécében az alábbi adatokat kérjük megadni:}

A cikk címe magyarul, zárójelben az angol cím

A szerző(k) neve (vezetéknév, a keresztnevet jelölő betü(k) - 3 szerzőig, háromnál több szerző esetén et al.), a levelező szerző neve, munkahelye és e-mail címe)

A folyóirat neve - a szokásos nemzetközi rövidítés szerint (PubMed), évszám, kötetszám, füzetszám, a cikk kezdő és utolsó oldalszáma

A referátumot elektronikus úton (Editorial Manager vagy e-mail: edit.budai@akademiai.hu) kérjük elküldeni. 